\title{
Is current institutional quality linked to legal origins and disease endowments? Evidence from Africa
}

\author{
Forthcoming in Research in International Business and Finance
}

\author{
Chukwunonye O. Emenalo (corresponding author) \\ Lagos Business School, Pan-Atlantic University \\ Km 22, Lekki-Epe Expressway, Ajah, Lagos \\ Email: cemenalo@lbs.edu.ng
}

Francesca Gagliardi

Hertfordshire Business School, University of Hertfordshire

Hatfield, Hertfordshire, AL10 9AB, UK

Email: f.gagliardi@herts.ac.uk

\begin{abstract}
This paper empirically assesses if and to what extent cross-country differences in institutions inherited from the past affect current institutional quality in Africa. Specifically, the work evaluates if legal origins and disease endowments explain cross-country differences in the quality of contemporary institutions that are widely considered to be important for financial system development and other economic outcomes, such as those related to creditor rights protection and the credit information infrastructure, as well as the judicial, legal property and insolvency systems. Empirical tests are carried out on a sample of 46 African former European colonies with data on current institutional quality from 2004 to 2013. The findings reveal that the legal origins hypothesis receives strong support in the data: historical factors, rooted in legal origins, have long-lasting effects on current institutional quality in the African context. Mixed evidence is instead found for the endowment view.
\end{abstract}

Keywords: Africa; institutions; law and finance; legal origins; disease endowments.

JEL classifications: G20, K20, O16, O55 


\section{Introduction}

The claim that financial system development matters for economic outcomes has received substantial support in the large body of literature on the finance and growth nexus (see, for example, Beck et al., 2005; Beck and Demirguc-Kunt, 2006; Boukhatem, 2016; Demirguc-Kunt et al., 2006; Fowowe, 2017; Ibrahim and Alagidede, 2018; Otchere et al., 2017). ${ }^{1}$ Significant differences in financial system development can be observed among countries, regardless of how this is measured. This has led researchers to investigate the determinants of financial system development. Institutions have been found to be important in this context (Beck and Levine, 2005).

Scholars have identified both historical and current institutional factors as determinants of financial system development (Beck and Levine, 2005). Historical determinants are argued to trace back to the years of European colonization (see Emenalo et al., 2018 for recent evidence on Africa). The legal origins hypothesis, which builds on the work of La Porta, Lopez-de-Silanes, Shleifer, and Vishny (see La Porta et al., 1997, 1998 and more recently La Porta et al., 2013), argues that the legal traditions brought by colonizers shaped the development path followed by different countries. Hence, historically determined differences in legal traditions explain current differences in financial systems and, more generally, institutional development. The endowment theory emphasizes, instead, the roles of geography and the disease environment in shaping institutional development (Acemoglu et al., 2001; Beck et al., 2003). This view is based on three elements. First, the observation that in some territories Europeans settled and created institutions

${ }^{1}$ See Levine (2005) and Beck (2013) for recent reviews, with Beck (2013) noting that the relationship between financial system development and economic development is not linear and recent papers such as Arcand et al. (2015) pointing to potential dangers of overheated financial systems, especially in the wake of the 2008 global financial and economic crisis. Murinde (2012) highlights mixed empirical results on the relationship between financial system development and economic growth in Africa: although there is a long-run link between financial system development and economic growth in African countries, the direction of causality is unclear as some studies find a bidirectional causality between finance and growth (Ahmed, 2010). 
that supported the development of those colonies, while in other territories Europeans aimed to extract as much as possible, hence created institutions that facilitated extraction. Secondly, the colonization strategy was influenced by the feasibility of settlement: extractive colonies were created in territories with unfavorable endowments and high mortality rates, while settler colonies were formed in areas where endowments were more favorable to settlement. Finally, the institutions created in settler and extractive colonies endured after independence, shaping the current path of development in financial systems and in other economic spheres (Acemoglu et al., 2001; Beck et al., 2001; Beck et al., 2003; Easterly and Levine, 2003; Oto-Peralias and Romero-Avila, 2014).

Regarding the current institutional determinants of financial system development, which were the early focus of the law and finance research, ${ }^{2}$ legal institutions which enable and protect contracting and property rights are seen as key in determining cross-country variation in financial system development. Empirical studies in this line of inquiry show that the quality of a country's legal rights protection and credit information infrastructure, as well as the efficiency of its judicial, legal property and insolvency systems are significantly and positively correlated to the degree of development of its financial system (see, among others, Beck et al., 2006; Beck, 2013; Djankov et al., 2008, 2007; Siems and Deakin, 2010; Haselmann et al., 2010; Pistor et al., 2000; Skosples, 2012). So, then, what explains cross-country differences in these current institutions?

${ }^{2}$ As Schnyder et al. (2018) note "The range of political and economic outcomes explained by legal variables progressively increased. The 10-year review paper by La Porta et al. (2008a, p. 292) states that legal aspects were shown to explain a large number of economic outcomes such as the control premium on sales of blocks of shares, private credit, interest rate spread, labour market participation rates, unemployment levels, corruption, the size of the unofficial economy, the time to evict a non-paying tenant and the time to collect a bounced check." (p. 6) 
This paper explores whether, and to what extent, differences in institutions inherited from the past should be taken as a possible explanation for differences in the quality of contemporary ones. The paper contributes to the literature that looks at historical and current institutional determinants of economic outcomes through the legal origins and disease endowment views. In this context, for example, Beck et al. (2001) find that legal traditions explain cross-country differences in current financial development. Their result holds also when controlling for a country's disease endowment. They argue it is however difficult to identify the precise channels through which legal traditions influence economic outcomes. Against this backdrop, the core argument of the present study is that historical factors rooted in a country's legal origins and disease endowment may have a significant impact on the quality of current institutions, such as creditor rights protection and information-sharing institutions, and that these current institutions act as channels through which the historical factors affect current economic results in the financial domain and elsewhere.

The intuition behind the above argument is that the institutions inherited from the past have long-lasting effects on economic outcomes due to mechanisms of path dependence, lock-in and cumulative causation (Gagliardi, 2008). In essence, current institutions and economic outcomes are influenced by past trajectories of institutional and economic performance. This is due to the fact that once chance forces select a particular path, this may become self-reinforcing, leading to cumulative causation effects, ${ }^{3}$ and may become locked-in regardless of the advantages of other paths (David, 1985; Arthur, 1989; North, 1990). ${ }^{4}$ Both current and future outcomes are therefore

\footnotetext{
${ }^{3}$ Cumulative causation implies that the process of development is generally divergent rather than convergent, both at regional and national levels. On the notion of cumulative causation see Young (1928), Myrdal (1957), Kaldor (1967) and Kapp (1976).

${ }^{4}$ David (2007) points out that the term lock-in describes the entry of a system into a trapping region. He further argues that once a system enters such a region, alterations in the path that becomes established are mainly determined by external effects and unanticipated effects of choices. These must be able to change the system's configuration or transform the structural relationships among agents.
} 
influenced by the patterns previously observed. Put it differently, history matters. The issue of institutional complementarities, that is the interdependencies arising among institutions, brings further dimensions into the argument that historical circumstances condition current outcomes. Complementarities generate increasing returns among institutions and may lead to mutually reinforcing patterns of behavior, hence reinforcing path dependent outcomes (Gagliardi, 2019).

The focus of the empirical work is the African context, which to date is a relatively unexplored case. The European colonization of nearly all African countries and the dominance of two major European colonizers, Britain and France, make Africa a relevant context to test and evaluate the research question under examination. The African financial system is largely dominated by the banking sector given that only a few countries have active organized equity markets (Beck et al., 2011). For this reason, only current institutional factors that may exert their impact predominantly on the banking sector are taken into account. The study is carried out on the ten-year period 2004-2013 for a sample of 46 African former European colonies using data on a set of current institutions that the extant literature has identified to be important for financial system development and other economic outcomes.

The results lend strong support to the legal origins hypothesis. African countries of British legal origin are found to offer stronger protection of legal rights in lending and have a more developed credit information infrastructure compared to French legal origin countries. The crosscountry regressions also reveal that in the African context the efficiency of the judicial system, the legal property system and the insolvency system is higher in British common law countries than in French civil law ones. As far as the endowment hypothesis is concerned, this finds some support in the data. The findings evidence that the credit information infrastructure is less developed and the legal property system is less efficient in African countries where the disease 
endowment is more conducive to malaria, hence in former colonies where Europeans set-up extractive institutions. Overall considered, the empirical evidence gathered corroborates the core argument of the study: historical factors have long-lasting effects on current institutional quality across Africa.

The remainder of the paper is organized as follows. Section 2 presents a brief literature review of the legal origins theory as well as of the endowment view. Section 3 illustrates the core research question under investigation, spelling out the empirical hypotheses. It also describes the empirical specification adopted and the econometric methods used. Section 4 presents the empirical findings and the robustness checks performed. Finally, Section 5 discusses the results and concludes.

\section{Literature review}

As previously introduced, both the legal origins and the endowment theories are concerned with disentangling the effects of colonization on economic outcomes and trajectories of institutional development in former colonies. They identify exogenous explanatory variables that, being related to the effects of colonization, may account for the observable cross-country variation in current institutions. Although these two views identify very different causal mechanisms in their accounts, the explanations they offer, Beck et al. (2003) argue, are not necessarily mutually exclusive.

The legal origins theory, which builds on the seminal work of La Porta, Lopez-de-Silanes, Shleifer, and Vishny (see La Porta et al., 1997, 1998 and more recently La Porta et al., 2013), argues that the quality of law is a key determinant of economic outcomes and is function of a country's legal origin. Four legal origins are distinguished in this approach: British common law, 
French civil law, German civil law, and Scandinavian civil law. In its classic typology, British common law countries favor economic activities centered on private contracting to economic activities based on state-desired allocations, while countries of civil law legal origin prefer statedesired allocations. Supported by a large body of empirical evidence and, at the same time, countered by various alternative accounts, legal origins are argued to explain a range of economic outcomes. For example, law and finance studies generally find that aspects of the legal and judicial system associated with the common law tradition produce better outcomes than those associated with civil law countries (La Porta et al., 2008a). Specifically, countries of British legal origin are shown to offer better protection of contracting and private property rights, have better institutional enforcement and are more suited to financial contracting than French legal origin countries (Djankov et al., 2007; La Porta et al., 2013).

Over the last 20 years the so-called law and finance school, as Schnyder et al. (2018) point out, has become an important line of research in socio-economic and management studies, and has been very influential not only in academia but also in economic policy. The law and finance framework has become the dominant legal approach in comparative economics, as well as in comparative management, corporate governance studies, international business and finance. ${ }^{5} \mathrm{~A}$ growing body of work in the area of international business and finance examines the impact of legal origins and institutional quality on a wide range of outcomes, both at country and firm level. Hearn and Filatotchev (2019), for example, use legal origins alongside proxies of formal and informal institutional quality to study the effect of private equity ownership on founder's retention as CEO in Initial Public Offerings (IPOs) in emerging markets. Hearn et al. (2018) also

\footnotetext{
${ }^{5}$ Beside many accolades the law and finance theory has also been the object of strong criticism for issues ranging from bias in variable selection and coding, to modelling problems, to the neglect of factors other than law, such as history. See Schnyder et al. (2018) for more details on these criticisms.
} 
account for institutional quality and legal origins while conducting an empirical work on postIPO retained ownership of private equity in business group constituent firms as compared to unaffiliated companies. As far as corporate governance focused studies are concerned, Filatotchev et al. (2013) call for cross-national corporate governance research to take into account the impact of differences in legal systems and in the institutional features of different contexts on corporate governance practices. Hearn (2014) looks instead at the impact of a range of institutional quality measures in inhibiting board of directors' self-reward behavior in North Africa, finding evidence that government effectiveness and corruption control are important inhibitors.

Turning now to discuss the endowment view, this argues that the geography, topology and disease environment of a country shape the development of all institutions, including legal and financial ones (Beck et al., 2001). In a first mechanism invoked by Gallup et al. (1998), the emphasis is on the impact of endowments on production and economies of scale in agriculture. Lands with high rates of disease and poor agricultural yields (the tropics, for example) do not support large scale farming which is necessary for specialization, hence innovation, institutional development and economic growth. These lands are thus expected to have lower institutional quality. Acemoglu et al. (2001), on the other hand, identify a different mechanism through which endowments influence the development of institutions. They note, as Beck et al. (2001) emphasize, that Europeans encountered a variety of conditions in the territories they colonized. In some lands they found it difficult to settle. This led to the establishment of extractive colonies in inhospitable territories, where the focus was on extracting local resources. Conversely, other areas presented hospitable conditions, conditions conducive to settlement. Here Europeans formed settlement colonies where institutions aimed at promoting development were set-up. The 
institutions created in settler and extractive colonies endured after independence, shaping the current path of development in financial systems and in other economic spheres.

Easterly and Levine (2003) address the question of whether the endowments of tropics, germs and crops affect economic development through institutions or policies on development. They use Acemoglu et al.'s (2001) settler mortality rates as a first indicator of endowments. Settler mortality measures the disease environment as European settlers arrived, hence this is an exogenous indicator of germs. A second proxy of disease endowments is the latitude of a country. The underpinning idea is that countries which are closer to the equator tend to have a more tropical, hence less hospitable, environment. The third proxy of disease environment is related to crops and minerals, and is captured through dummies accounting for whether a country produced any leading commodities. The expectation is that land endowment is what makes it possible to produce or mine a specific commodity. Using cross-country estimations for 72 observations, Easterly and Levine (2003) find that each of these three measures of endowments affects development only though institutions.

Beck et al. (2003) work on a cross-country sample of 70 former colonies to assess whether legal origins and disease endowment are historical determinants of financial development. Using different measures of financial development (namely, private credit to GPD, stock market development and effectiveness of the legal property system), their findings provide evidence supporting both theories. However, initial endowments are found to explain more of the crosscountry variation in financial intermediation and stock market development.

The present study focuses on African countries to test the above theoretical predictions on the impact of cross-country differences in institutions inherited from the past on variation in current institutional quality. It does so by focusing on six main types of contemporary 
institutions that are considered to be important for financial system development and other economic outcomes in the prevalent law and finance literature. These are: the quality of legal rights in lending (Deakin et al., 2010; Djankov et al., 2007); the quality of the credit information infrastructure (Brown et al., 2009; Djankov et al., 2007); the efficiency of the judicial system (Beck et al., 2006; Brown et al., 2009; Djankov et al., 2007; McDonald and Schumacher, 2007); the efficiency of the legal property system (De Soto, 2001; McDonald and Schumacher, 2007), and the efficiency of the insolvency system (Djankov et al., 2008).

\section{Empirical question, methodology and data}

This paper empirically assesses whether and to what extent cross-country differences in institutions inherited from the past affect current institutional quality in Africa. The work evaluates if explanations put forward by the legal origins and disease endowment theories explain cross-country differences in contemporary institutions that matter for financial system development and other economic outcomes. The following hypotheses are tested in the econometric study:

H1: Current institutional quality is higher in African countries of British common law legal origin than in those of French civil law legal origin. Specifically, ceteris paribus, countries of British legal origins display: stronger protection of creditor rights; more developed credit information infrastructures; more efficient judicial systems; more efficient legal property systems; more efficient insolvency systems.

H2: Current institutional quality is lower in African countries where, during European colonization, the disease endowment was conducive to the establishment of extractive colonies than in countries where the disease endowment was more favorable to the creation of 
settlement colonies. Ceteris paribus, countries with a higher malaria burden display: weaker protection of creditor rights; less developed credit information infrastructures; less efficient judicial systems; less efficient legal property systems; less efficient insolvency systems.

Africa is a little explored yet good context of study for a number of reasons. First, being a group of former British and French colonies that gained independence relatively recently, African countries provide an ideal setting to test the predictions of the legal origins hypothesis. Africa's colonial experience can, indeed, justify the claim that its countries' legal origin is exogenous (La Porta et al., 2008a). Second, given that the settlement strategies adopted by colonizers may have been strongly influenced by Africa's conduciveness to malaria (Kiszewski et al., 2004; Sachs and Chambers, 2009), it is relevant to assess the empirical relevance of the disease endowment theory across Africa.

Africa, de Sousa and Lochard (2012) argue, is a more homogeneous area with respect to the pre- and post-colonial context than other former colonies are. As pointed out by Honohan and Beck (2007), African countries can be considered as a relatively homogeneous group with respect to a number of political, institutional and socio-economic dimensions, such as scale (low gross domestic product (GDP) and sparse population), informality (the existence of large informal sectors), governance problems in the private and public sectors, and shocks (conflicts, famine, economic and politico-societal meltdowns). On the other hand, they are sufficiently heterogeneous along the core dimensions that are being investigated in the present study to enable cross-country comparisons.

It is worth clarifying that the paper only looks at countries which were former European colonies. This is so as to maintain the exogenous nature of the historical institutional variables taken into consideration. Hence countries not exposed to European colonization from the 
nineteenth to the twentieth century have been excluded, along with countries with missing data issues. Given this sample selection strategy, the empirical work is based on 46 African countries ${ }^{6}$ over the ten-year period 2004 - 2013. The selection of this period has been dictated by the fact that the measures of current institutional quality coming from the World Bank Doing Business Project, which in this paper is the main data source for these variables, are available starting from 2004. ${ }^{7}$ In addition, the methodology employed by the Doing Business Project was changed in 2014. This resulted in the values of some measures not being exactly comparable to their 2014 and subsequent values. Hence, for the purpose of data comparability, 2013 was chosen as the end period of the data series employed. ${ }^{8}$

The sub-sections below discuss the historical and current institutional variables included in the empirical models and illustrate the empirical specification adopted, as well as the econometric methods used. Table 1 reports all the variables, including their definition, measurement and source.

\footnotetext{
${ }^{6}$ The list of the African countries included in this study is provided in Appendix 1.

${ }^{7}$ The Doing Business Project used the methodologies developed by the research works of La Porta and colleagues to construct its indices of legal institutions claimed to be important for the well-functioning of private sectors (World Bank, 2017c). The large database developed with these indices, despite controversies surrounding the Doing Business Project, has been increasingly used for policy recommendations and reforms by international development organizations and individual governments (World Bank, 2013), as well as in academic research. Besley (2015, p. 100) writes that "since 2003, over 2,000 research articles have been published in peer-reviewed academic journals using this data, with more than 5,000 working papers being posted online". A recent study that used the Doing Business data is Djankov et al. (2018)

${ }^{8}$ The data webpage of the Doing Business Project reports the following: "Note: The data for Dealing with Construction Permits, Getting Electricity, Registering Property, Getting Credit, Protecting Minority Investors, Trading across Borders, Enforcing Contracts and Resolving Insolvency are not comparable between Doing Business 2014 [2013] and Doing Business 2015 [2014] due to methodological changes" (http://www.doingbusiness.org/Custom-Query)
} 


\subsection{Measuring Current Institutional Variables}

The dependent variables are proxies of current institutional quality. The quality of legal rights in lending is measured with the strength of legal rights index (CRI) from the Doing Business Project. This measures the degree to which the rights of borrowers and creditors are protected through collateral laws and the degree to which the rights of secured creditors are protected through bankruptcy laws. CRI ranges from 0 to 10 and consists of eight items that refer to legal rights in collateral law and two items that refer to legal rights in bankruptcy law (World Bank, 2013). Higher index scores imply that collateral and bankruptcy laws are designed to protect the rights of borrowers and creditors in a way that is expected to facilitate financial contracting and expand credit availability.

The quality of the credit information infrastructure is proxied by the depth of credit information index (CII) produced by the Doing Business Project. This index measures the rules and practices that determine the availability of relevant information in public credit registries or private credit bureaus for credit analysis in different countries. The index takes on values between 0 and 6, with higher values being assigned to countries where more credit information is available (World Bank, 2013), hence indicating a more solid credit information infrastructure.

The efficiency of the judicial system is a further dimension of a country's current institutional infrastructure that is examined in the paper. To do so two measures, both compiled by the Doing Business Project and defining the enforcing contracts indicator, are used in the estimations. These are the time taken to enforce contracts (TEC) and the cost of enforcing contracts (CEC). ${ }^{9}$ The greater the value of these variables for a given country, the less efficient its judicial system is (World Bank, 2013).

\footnotetext{
${ }^{9}$ A third variable called procedures to enforce contracts was also part of the enforcing contracts indicator. This is no longer available on the Doing Business Project webpage that provides the historical datasets. Hence to ensure that
} 
To account for the efficiency of a country's legal property system, the empirical work uses three variables defining the registering property indicator of the Doing Business Project. These are: procedures to register property (PRP), time to register property (TRP) and cost to register property (CRP) (World Bank, 2013). The higher the value of these measures, the lower the efficiency of a country's legal property system.

Finally, to measure the efficiency of the insolvency system in a country, the recovery rate for creditors (RRC) is used as dependent variable in a further set of models. The recovery rate for creditors is a component of the resolving insolvency indicator of the Doing Business Project (World Bank, 2013). Higher values of this variable are associated with more efficient insolvency systems.

our results are replicable by other researchers we use only the components of the enforcing contracts indicator that cover our period of study and that are still available from the Doing Business Project webpage. 
Table 1

Variables: definition, measurement and source

\begin{tabular}{|c|c|c|c|}
\hline \multicolumn{4}{|c|}{ Current institutional variables } \\
\hline Variable & Definition / description & Measurement & Relevant source / reference \\
\hline $\begin{array}{l}\text { 1. Strength of legal } \\
\text { rights index } \\
(\mathrm{CRI})\end{array}$ & $\begin{array}{l}\text { The strength of legal rights is the degree to which } \\
\text { collateral and bankruptcy laws protect the rights } \\
\text { of borrowers and lenders and thus facilitate } \\
\text { lending. The legal rights relate to: whether a } \\
\text { category or all movable business assets may be } \\
\text { used as collateral without losing possession and } \\
\text { without having to describe the collateral; whether } \\
\text { a security right may extend to future assets and to } \\
\text { the products, proceeds or replacements of the } \\
\text { original assets; whether a description of debts and } \\
\text { obligations is permitted in collateral agreements } \\
\text { and registration documents; whether a collateral } \\
\text { registry for security interests over movable } \\
\text { property is in operation; whether secured } \\
\text { creditors are paid first when a debtor defaults } \\
\text { outside an insolvency procedure and when a } \\
\text { business is liquidated; whether secured creditors } \\
\text { either are not subject or are relieved or limited to } \\
\text { an automatic stay or moratorium on enforcement } \\
\text { procedures when a debtor enters a court- } \\
\text { supervised reorganization procedure; whether } \\
\text { parties can agree in a collateral agreement that the } \\
\text { lender may enforce its security right out of court. }\end{array}$ & $\begin{array}{l}\text { The index ranges from } 0 \text { to } 10 \text {, with higher scores } \\
\text { indicating better collateral and bankruptcy laws, } \\
\text { designed to expand access to credit. It includes } 8 \\
\text { aspects of legal rights in collateral law and } 2 \\
\text { aspects of bankruptcy law. Data from } 2004 \text { to } \\
2013 \text {. }\end{array}$ & $\begin{array}{l}\text { World Bank (2017a) } \\
\text { World Bank (2012) }\end{array}$ \\
\hline $\begin{array}{l}\text { 2. Depth of credit } \\
\text { information } \\
\text { index (CII) }\end{array}$ & $\begin{array}{l}\text { The depth of credit information index captures the } \\
\text { rules and practices affecting the coverage, scope } \\
\text { and accessibility of credit information available } \\
\text { through either a public credit registry or a private } \\
\text { credit bureau. Credit information relates to: } \\
\text { whether both positive credit information and } \\
\text { negative information is distributed; whether data } \\
\text { on both firms and individuals are distributed; }\end{array}$ & $\begin{array}{l}\text { The depth of credit information index ranges from } \\
0 \text { to } 6 \text {, with higher values indicating the } \\
\text { availability of more credit information to facilitate } \\
\text { lending decisions. Data from } 2004 \text { to } 2013 \text {. }\end{array}$ & $\begin{array}{l}\text { World Bank (2017a) } \\
\text { World Bank (2012) }\end{array}$ \\
\hline
\end{tabular}




\begin{tabular}{|c|c|c|c|}
\hline & $\begin{array}{l}\text { whether data from retailers, utility companies and } \\
\text { financial institutions are distributed; whether } \\
\text { more than } 2 \text { years of historical data are } \\
\text { distributed; whether data on loan amounts below } \\
1 \% \text { of income per capita are distributed; whether, } \\
\text { by law, borrowers have the right to access their } \\
\text { data in the largest credit registry or bureau in the } \\
\text { economy. }\end{array}$ & & \\
\hline $\begin{array}{l}\text { 3. Time to enforce } \\
\text { contracts (TEC) }\end{array}$ & $\begin{array}{l}\text { Time to enforce contracts is defined as the } \\
\text { number of calendar days to enforce contracts. The } \\
\text { stages of dispute resolution which are recorded in } \\
\text { this variable are: the completion of service of } \\
\text { process (time to file and serve the case); the } \\
\text { issuance of judgment (time for the trial and } \\
\text { obtaining the judgment); the moment of payment } \\
\text { (time for enforcement of the judgment). }\end{array}$ & $\begin{array}{l}\text { Time is measured as the average duration of each } \\
\text { stage of dispute resolution, starting from the } \\
\text { moment the plaintiff decides to file a lawsuit until } \\
\text { payment. This includes the days when actions } \\
\text { take place as well as the waiting periods in } \\
\text { between. Data from } 2004 \text { to } 2013 \text {. }\end{array}$ & $\begin{array}{l}\text { World Bank (2017a) } \\
\text { World Bank (2012) }\end{array}$ \\
\hline $\begin{array}{l}\text { 4. Cost to enforce } \\
\text { contracts (CEC) }\end{array}$ & $\begin{array}{l}\text { The cost to enforce contracts relates to three types } \\
\text { of costs: court costs, which include all court costs } \\
\text { and expert fees that the seller must advance to the } \\
\text { court, regardless of the final cost to the seller } \\
\text { (expert fees are included in court costs if they are } \\
\text { required by law or are used in practice); } \\
\text { enforcement costs, which are all costs that the } \\
\text { seller must advance to enforce the judgment } \\
\text { through a public sale of the buyer's movable } \\
\text { assets, regardless of the final cost to the seller; } \\
\text { average attorney fees, covering the fees that the } \\
\text { seller must advance to a local attorney to be } \\
\text { represented in the case. }\end{array}$ & $\begin{array}{l}\text { Cost to enforce contracts is measured as a } \\
\text { percentage of the claim, which is assumed to be } \\
\text { equivalent to } 200 \% \text { of income per capita. Data } \\
\text { from } 2004 \text { to } 2013 \text {. }\end{array}$ & $\begin{array}{l}\text { World Bank (2017a) } \\
\text { World Bank (2012) }\end{array}$ \\
\hline $\begin{array}{ll}5 . & \text { Procedures to } \\
\text { register property } \\
\text { (PRP) }\end{array}$ & $\begin{array}{l}\text { Procedures to register property is defined as any } \\
\text { interaction of the buyer or the seller, their agents } \\
\text { or the property with external parties, including } \\
\text { government agencies, inspectors, notaries and } \\
\text { lawyers. The variable captures all procedures that } \\
\text { are legally or in practice required to enable the } \\
\text { buyer to use the property to expand its business, } \\
\text { or as collateral in taking new loans, or to sell the } \\
\text { property to another business. }\end{array}$ & $\begin{array}{l}\text { This variable is measured as the number of } \\
\text { procedures necessary for a business (buyer) to } \\
\text { purchase a property from another business (seller) } \\
\text { and to transfer the property title to the buyer's } \\
\text { name. Data from } 2004 \text { to } 2013 \text {. }\end{array}$ & $\begin{array}{l}\text { World Bank (2017a) } \\
\text { World Bank (2012) }\end{array}$ \\
\hline
\end{tabular}




\begin{tabular}{|c|c|c|c|c|}
\hline & $\begin{array}{l}\text { Time to register } \\
\text { property (TRP) }\end{array}$ & $\begin{array}{l}\text { Time to register property is defined as the median } \\
\text { duration that property lawyers, notaries or registry } \\
\text { officials indicate is necessary to complete a } \\
\text { procedure in registering property. It is assumed } \\
\text { that: the minimum time required for each } \\
\text { procedure is } 1 \text { day; the buyer does not waste time } \\
\text { and commits to completing each procedure } \\
\text { without delay; if procedures can be undertaken } \\
\text { simultaneously then they are but cannot start on } \\
\text { the same day; the parties involved are aware of all } \\
\text { requirements and their sequence; the fastest legal } \\
\text { procedure available and used by the majority of } \\
\text { property owners is chosen even if that requires an } \\
\text { additional cost; time spent on gathering } \\
\text { information is not considered. }\end{array}$ & $\begin{array}{l}\text { Time to register property is measured as the } \\
\text { number of calendar days that are required to } \\
\text { register property. Data from } 2004 \text { to } 2013 \text {. }\end{array}$ & $\begin{array}{l}\text { World Bank (2017a) } \\
\text { World Bank (2012) }\end{array}$ \\
\hline & $\begin{array}{l}\text { Cost to register } \\
\text { property (CRP) }\end{array}$ & $\begin{array}{l}\text { Cost to register property relates to the costs borne } \\
\text { by the buyer as well as those borne by the seller. } \\
\text { The variable records only the costs required by } \\
\text { law: fees; transfer taxes; stamp duties; any other } \\
\text { payment to the property registry, notaries, public } \\
\text { agencies or lawyers. }\end{array}$ & $\begin{array}{l}\text { Cost is expressed as a percentage of the property } \\
\text { value, assumed to be equivalent to } 50 \text { times } \\
\text { income per capita. In cases where cost estimates } \\
\text { differ among sources, the median reported value } \\
\text { is used. Data from } 2004 \text { to } 2013 \text {. }\end{array}$ & $\begin{array}{l}\text { World Bank (2017a) } \\
\text { World Bank (2012) }\end{array}$ \\
\hline & $\begin{array}{l}\text { Recovery rate } \\
\text { for creditors } \\
\text { (RRC) }\end{array}$ & $\begin{array}{l}\text { The recovery rate for creditors is defined as the } \\
\text { present value of the proceedings from business } \\
\text { reorganization, liquidation or debt enforcement } \\
\text { (foreclosure), net of the costs of the proceedings, } \\
\text { and of the value lost as a result of the time the } \\
\text { money remains tied up in insolvency proceedings } \\
\text { (including the loss of value due to depreciation). } \\
\text { The variable takes into account whether a } \\
\text { business emerges from the proceedings as a going } \\
\text { concern or the assets are sold piecemeal. }\end{array}$ & $\begin{array}{l}\text { The recovery rate for creditors is measured as } \\
\text { cents on the dollar recouped by creditors through } \\
\text { reorganization, liquidation or debt enforcement } \\
\text { (foreclosure) proceedings. The computation is } \\
\text { based on end-2010 lending rates from the } \\
\text { International Monetary Fund's International } \\
\text { Financial Statistics, supplemented with data from } \\
\text { central banks and the Economist Intelligence } \\
\text { Unit. Data from } 2004 \text { to } 2013 \text {. }\end{array}$ & $\begin{array}{l}\text { World Bank (2017a) } \\
\text { World Bank (2012) }\end{array}$ \\
\hline \multicolumn{5}{|c|}{ Historical variables } \\
\hline & $\begin{array}{l}\text { French legal } \\
\text { origin (FLO) }\end{array}$ & $\begin{array}{l}\text { A dummy variable that identifies the legal origin } \\
\text { of the company law or commercial code of each } \\
\text { sample African country. }\end{array}$ & $\begin{array}{l}\text { The variable takes on the value of } 1 \text { for African } \\
\text { countries categorized as part of the French legal } \\
\text { origin family and } 0 \text { for British legal origin } \\
\text { countries. }\end{array}$ & La Porta et al. (2008b) \\
\hline
\end{tabular}




\begin{tabular}{|c|c|c|c|}
\hline $\begin{array}{l}\text { 10. Malaria stability } \\
\text { index (MSI) }\end{array}$ & $\begin{array}{l}\text { The malaria stability index for a country is the } \\
\text { average contribution of regionally dominant } \\
\text { vector mosquitos to the potential transmission } \\
\text { intensity of malaria. }\end{array}$ & $\begin{array}{l}\text { The index is measured as a function of climatic } \\
\text { factors that determine the required habitat of the } \\
\text { dominant malaria vector and of biological } \\
\text { properties of the region-specific dominant vectors. } \\
\text { Higher values of the index are associated with a } \\
\text { higher malaria burden. }\end{array}$ & $\begin{array}{l}\text { McCord (2012) } \\
\text { Carstensen and Gundlach } \\
\text { (2006) } \\
\text { Kiszewski et al. (2004) }\end{array}$ \\
\hline \multicolumn{4}{|c|}{ Control variables } \\
\hline $\begin{array}{l}\text { 11. GDP per capita } \\
\text { (GCAP) }\end{array}$ & $\begin{array}{l}\text { GDP per capita is the gross domestic product of a } \\
\text { country converted to international dollars using } \\
\text { purchasing power parity rates, and then } \\
\text { normalized by population. An international dollar } \\
\text { has the same purchasing power over GDP as the } \\
\text { U.S. dollar has in the United States. GDP at } \\
\text { purchaser's prices is the sum of gross value added } \\
\text { by all resident producers in the economy plus any } \\
\text { product taxes and minus any subsidies not } \\
\text { included in the value of the products. }\end{array}$ & $\begin{array}{l}\text { GDP per capita is measured as the natural } \\
\text { logarithm of the annual GDP per capita based on } \\
\text { purchasing power parity. Data are in constant } \\
2011 \text { international dollars. Data from } 2004 \text { to } \\
2013 \text {. }\end{array}$ & World Bank (2017b) \\
\hline $\begin{array}{l}\text { 12. Catholicism } \\
\text { (CAT) }\end{array}$ & $\begin{array}{l}\text { A dummy variable that identifies sample African } \\
\text { countries where Catholicism is the prevalent } \\
\text { religion. }\end{array}$ & $\begin{array}{l}\text { The variable takes on the value of } 1 \text { if Catholics } \\
\text { are the dominant religious group in a country and } \\
\text { zero otherwise. }\end{array}$ & $\begin{array}{l}\text { Authors' coding based on the } \\
\text { percentage of religious groups } \\
\text { in different countries as given } \\
\text { in La Porta et al. (1999). }\end{array}$ \\
\hline 13. Islam (ISLAM) & $\begin{array}{l}\text { A dummy variable that identifies sample African } \\
\text { countries where Islam is the prevalent religion. }\end{array}$ & $\begin{array}{l}\text { The variable takes on the value of } 1 \text { if Muslims } \\
\text { are the dominant religious group in a country and } \\
\text { zero otherwise. }\end{array}$ & $\begin{array}{l}\text { Authors' coding based on the } \\
\text { percentage of religious groups } \\
\text { in different countries as given } \\
\text { in La Porta et al. (1999). }\end{array}$ \\
\hline $\begin{array}{l}\text { 14. Other religion } \\
\text { (OTHR) }\end{array}$ & $\begin{array}{l}\text { A dummy variable that identifies sample African } \\
\text { countries where the dominant religious group is } \\
\text { neither Protestant, nor Catholic or Islamic. }\end{array}$ & $\begin{array}{l}\text { The variable takes on the value of } 1 \text { if the } \\
\text { dominant religious group in a country is from a } \\
\text { religion other than Protestantism, Catholicism, } \\
\text { and Islam, and zero otherwise. }\end{array}$ & $\begin{array}{l}\text { Authors' coding based on the } \\
\text { percentage of religious groups } \\
\text { in different countries as given } \\
\text { in La Porta et al. (1999). }\end{array}$ \\
\hline $\begin{array}{l}\text { 15. Ethnic } \\
\text { fractionalization } \\
\text { index (EF) }\end{array}$ & $\begin{array}{l}\text { The ethnic fractionalization index is the } \\
\text { probability that two randomly selected individuals } \\
\text { in a country belong to different ethnic groups. } \\
\text { The variable is a measure of ethnic fragmentation. }\end{array}$ & $\begin{array}{l}\text { The computation of this variable identifies ethnic } \\
\text { groups in a country based on the population } \\
\text { distribution by race. Higher values of the index } \\
\text { imply higher ethnic fragmentation. }\end{array}$ & Alesina et al. (2003) \\
\hline $\begin{array}{l}\text { 16. Population } \\
\text { density }\end{array}$ & $\begin{array}{l}\text { Population density is a measure of population by } \\
\text { square kilometer of land in each sample country. }\end{array}$ & $\begin{array}{l}\text { The variable is computed as midyear population } \\
\text { over land area in square kilometers. Data from }\end{array}$ & World Bank (2017b) \\
\hline
\end{tabular}




\begin{tabular}{|l|l|l|l|}
\hline & & 2004 to 2013. & \\
\hline 17. Political stability & $\begin{array}{l}\text { The political stability and absence of violence } \\
\text { index captures perceptions of the likelihood that } \\
\text { the government will be destabilized or } \\
\text { overthrown by unconstitutional or violent means, } \\
\text { including politically-motivated violence and } \\
\text { terrorism. }\end{array}$ & $\begin{array}{l}\text { The variable ranges from approximately -2.5 to } \\
\text { 2.5, with higher values indicating a relatively } \\
\text { more stable political system. The indicator is } \\
\text { based on a large number of variables obtained } \\
\text { from over 30 data sources capturing perceptions } \\
\text { as reported by survey respondents, non- } \\
\text { governmental organizations, commercial business } \\
\text { information providers and public sector } \\
\text { organizations. Using an unobserved components } \\
\text { model, these variables are then standardized and, } \\
\text { factoring in margins of error, an average indicator } \\
\text { of political stability is constructed as a weighted } \\
\text { average of the underlying source variables. Data } \\
\text { from 2004 to 2013. }\end{array}$ & $\begin{array}{l}\text { World Bank (2016) } \\
\text { Kaufmann et al. (2010) }\end{array}$ \\
& & & \\
\hline
\end{tabular}

The taxonomy has been drawn from the literature discussed in Section 2 and the variables presented in Sections 3.1-3.3. 


\subsection{Measuring Historical Institutional Variables}

Using data from La Porta et al. (1999) and La Porta et al. (2008b), this paper measures a country's legal origin through the use of a dummy variable labeled 'French legal origin' (FLO). This is equal to 1 for countries that are classed as French civil law and zero otherwise. The omitted group for the 'French legal origin' dummy is the group of countries that are classified as British common law (that is British legal origin). Out of the 46 African former European colonies that are included in the full sample, 30 are categorized as French legal origin and 16 are classified as British legal origin.

The disease endowment theory is tested using the malaria stability index (MSI). ${ }^{10}$ Developed by Kiszewski et al. (2004), this variable measures the disease endowment of African former European colonies and has been widely used in the literature on economic development (Carstensen and Gundlach, 2006; Gennaioli et al., 2014). ${ }^{11}$ Given that higher values of the malaria stability index are associated with a higher malaria burden, hence with environments leading to the set-up of extractive colonies, the malaria stability index is expected to have a negative impact on the quality of current institutions. ${ }^{12}$

\footnotetext{
10 The malaria stability index is based on biological and climatic variables and is constructed so as to make it an exogenous measure of geographic areas that are malaria endemic. Kiszewski et al. (2004, p. 486) state that this index was developed "based on the most powerful intrinsic properties of anopheline mosquito vectors of malaria that interact with climate to determine vectoral capacity. Because this index [malaria stability index] examines potential transmission stability, it includes regions where malaria is not currently transmitted, but where it had been transmitted in the past or where it might be transmitted in the future".

${ }^{11}$ The settler mortality rates of Acemoglu et al. (2001) could not be used for this study as these data are not available for all the sample African countries.

${ }^{12}$ Rather than measuring current malaria fatalities or infections, the malaria stability index proxies for African geographical areas and climates that have historically been conducive to malaria infection and transmission and that therefore posed a legal threat to human beings. Hence this index is a suitable proxy for the malaria disease endowment encountered by Europeans during colonization times.
} 


\subsection{The Econometric Specification}

The dependent variables used in the empirical models are the current institutional variables illustrated in Section 3.1. Historical variables, namely legal origins and disease endowment, are instead the main explanatory variables (see Section 3.2). Several additional factors that may affect current institutional quality are included in the empirical model as controls. GDP per capita (GCAP) is used to control for demand side factors that may be driving cross-country differences in institutional quality. Previous studies have documented that countries with higher income tend to have more effective current institutions (Djankov et al., 2007; La Porta et al., 2008a). Hence, GCAP is expected to be positively related to institutional quality.

Religious composition across the sample countries is also examined. From the seminal work of Max Weber (1905), religion is seen as a determinant of capitalist institutions influencing national views on property rights, competition and the role of the state (La Porta et al., 1999; Stulz and Williamson, 2003). The empirical analysis captures the possible effect of religion on current institutional quality through three dummy variables, proxying for the religious affiliation of the majority of the population in each sample country (as in the classification drawn by La Porta et al., 1999). Using 'Protestantism' as the omitted group, 'Catholicism' (CAT) and 'Islam' (ISLAM) are equal to 1 if the religious affiliation of the majority of the population in a country is Catholicism or Islam, respectively, and zero otherwise. 'Other Religion' (OTR) is equal to 1 if the religious affiliation of the majority of the population in a country is neither Catholicism nor Islam nor Protestantism and zero otherwise. ${ }^{13}$ Earlier works have found that institutional quality tends to be higher in countries where Protestantism is the main religion than in Catholic or Islamic countries (Beck et al., 2003; McCleary and Barro, 2006). Specifically, Protestant

\footnotetext{
${ }^{13}$ Of the 46 sample countries, 11 are included in the 'Catholicism' group, 16 in the 'Islam' group, 16 in the 'Other Religions' group, and 3 in the 'Protestantism' group.
} 
countries display less government intervention and better protection of property rights (La Porta et al., 1999); stronger support for legal institutions and institutional enforcement (Arrunada, 2010); stronger creditor rights protection and better enforcement of rights (Stulz and Williamson, 2003; Djankov et al., 2007).

Ethnic fractionalization is also accounted for in the empirical model as a further potential factor affecting institutional quality. Ethnically diverse countries are more socially polarized, hence more likely to have institutions that do not clearly delineate and protect contracting and property rights (Ayyagari et al., 2008; Beck et al., 2003; Easterly et al., 2006). Institutional quality is argued to be lower in highly ethnically diverse economies because those in power tend to implement policies that expropriate resources from other ethnic groups, restricting their rights, and obstruct the growth of sectors that threaten the ruling group (Alesina et al., 1999; Easterly and Levine, 1997). In this context, as noted by Emenalo et al. (2018), ethnic divisions may promote intra-ethnic transactions based on kinship ties and reputation rather than inter-ethnic transactions based on effective legal institutions and enforcement systems (Carr and Landa, 1983). In this paper the impact of ethnic fractionalization is captured through the updated ethnic fractionalization index (EF) compiled by Alesina et al. (2003). The index is based on a measure of ethnicity that goes beyond language and includes racial characteristics, such as skin color and racial origin.

Two further controls are included in the empirical model. The World Governance political stability and absence of violence/terrorism indicator (henceforth, PS) is used to control for political stability. This indicator captures 'perceptions of the likelihood that the government will be destabilized or overthrown by unconstitutional or violent means, including politicallymotivated violence and terrorism' (Kaufmann et al., 2010: 4). Higher values of the political 
stability indicator, which ranges between -2.5 and 2.5 approximately, indicate a relatively more stable political system and this should have a positive impact on institutional quality. Finally, given that population density (PD) is argued to affect the development of institutions (Beck et al., 2011), this variable is also included in the models.

The regression analysis exploits the between-country variation in the explanatory variables given that the relatively time-invariant nature of the historical institutional variables leaves little, if any, within-country variation in the sample. The data are therefore averaged over the ten-year period 2004-2013 to obtain a cross-section of 46 African former European colonies. Given this new data structure the Ordinary Least Squares (OLS) method is an adequate technique to estimate the effects of historical institutional variables on current institutional variables. ${ }^{14}$ The estimating equation for each of the OLS models tested is specified as:

$$
y_{i}=\alpha+\beta_{1} x_{1 i}+\beta_{2} x_{2 i}+\beta_{3} x_{3 i}+u_{i}
$$

In (1) index $i$ refers to individual countries. In each model the dependent variable is one of the proxies of current institutional quality illustrated in Section 3.1. On the right hand side, $x_{1 i}$ is the legal origin of country $i ; x_{2 i}$ is the disease endowment of country $i ; x_{3 i}$ is the vector of controls in country $i$ and includes: GDP per capita, religion dummies, the ethnic fractionalization index, the political stability indicator, and population density. Finally, $u_{i}$ is the error term summarizing time-invariant unobserved country characteristics. Table 2 reports the main summary statistics of the variables used in the estimations, while Table 3 presents the correlation matrix.

\footnotetext{
${ }^{14}$ OLS are a suitable modeling choice when, as in the present case, the averaged data is in cross-sectional form and the core independent variables are historical variables that represent events which happened long before those of the dependent variables (Alesina et al., 2003; La Porta et al., 1999). The OLS estimation method has been used by related studies in this line of literature to estimate cross-sectional data (Beck et al., 2003; Djankov et al., 2007; La Porta et al., 2008a, 1998).
} 
Table 2

Summary statistics

\begin{tabular}{lrrrrr}
\hline Variable & Observations & Mean & Std. dev. & Minimum & Maximum \\
\hline Strength of legal rights index (CRI) $^{+}$ & 46 & 4.73 & 1.93 & 1.11 & 10.00 \\
Depth of credit information index (CII) $^{+}$ & 46 & 0.86 & 1.49 & 0.00 & 5.70 \\
Time to enforce contracts (TEC) $^{+}$ & 46 & 672.59 & 269.99 & 276.00 & 1715.00 \\
Cost to enforce contracts (CEC) $^{*}$ & 46 & 50.06 & 32.39 & 14.30 & 144.26 \\
Procedures to register property (PRP) $^{+}$ & 46 & 6.42 & 2.06 & 3.50 & 13.11 \\
Time to register property (TRP) $^{+}$ & 46 & 82.43 & 60.68 & 11.00 & 295.00 \\
Cost to register property (CRP) $^{*}$ & 46 & 10.37 & 5.17 & 1.38 & 21.06 \\
Recovery rate for creditors (RRC) $^{*}$ & 46 & 20.94 & 16.09 & 0.00 & 58.39 \\
French legal origin (FLO) $^{*}$ & 46 & 0.65 & 0.48 & 0.00 & 1.00 \\
Malaria stability index (MSI) $^{+}$ & 46 & 10.64 & 8.40 & 0.00 & 31.55 \\
GCAP (GCAP) $^{\sim}$ & 46 & 7.96 & 0.99 & 6.37 & 10.68 \\
Catholicism (CAT) $^{*}$ & 46 & 0.24 & 0.43 & 0.00 & 1.00 \\
Islam (ISLAM) & 46 & 0.35 & 0.48 & 0.00 & 1.00 \\
Other religion (OTHR) $_{\text {Ethnic fractionalization index (EF) }}^{+}$ & 46 & 0.35 & 0.48 & 0.00 & 1.00 \\
Population density (PODEN) $^{+}$ & 46 & 0.62 & 0.25 & 0.00 & 0.93 \\
Political stability (PS) $^{+}$ & 46 & 87.32 & 120.37 & 2.61 & 612.40 \\
\hline
\end{tabular}

For the description of the variables and their sources see Table 1. * In percentage terms; + in units; in natural logarithm of GDP per capita at purchasing power parity in constant 2011 international dollars; \# in number of people per square $\mathrm{km}$ of land area. All other variables are dummies. 
Table 3

Pairwise correlation matrix

\begin{tabular}{|c|c|c|c|c|c|c|c|c|c|c|c|c|c|c|c|c|c|}
\hline & CRI & CII & TEC & CEC & PRP & TRP & CRP & RRC & FLO & MSI & GCAP & CAT & ISLAM & OTHR & $\mathrm{EF}$ & PODEN & PS \\
\hline CRI & 1.00 & & & & & & & & & & & & & & & & \\
\hline CII & 0.23 & 1.00 & & & & & & & & & & & & & & & \\
\hline TEC & $-0.35^{*}$ & -0.06 & 1.00 & & & & & & & & & & & & & & \\
\hline CEC & 0.05 & $-0.25 *$ & -0.15 & 1.00 & & & & & & & & & & & & & \\
\hline PRP & $0.26 *$ & -0.06 & 0.12 & 0.03 & 1.00 & & & & & & & & & & & & \\
\hline TRP & -0.14 & $-0.25 *$ & 0.24 & 0.06 & 0.01 & 1.00 & & & & & & & & & & & \\
\hline CRP & -0.14 & $-0.27 *$ & 0.03 & $0.27 *$ & -0.12 & 0.07 & 1.00 & & & & & & & & & & \\
\hline RRC & $0.26^{*}$ & $0.36^{*}$ & 0.02 & $-0.32 *$ & 0.20 & -0.21 & $-0.29 *$ & 1.00 & & & & & & & & & \\
\hline FLO & $-0.82 *$ & $-0.28 *$ & 0.23 & -0.02 & $-0.25^{*}$ & $0.26^{*}$ & $0.35^{*}$ & $-0.32 *$ & 1.00 & & & & & & & & \\
\hline MSI & -0.06 & $-0.47 *$ & -0.04 & -0.04 & 0.23 & -0.16 & 0.07 & $0.52 *$ & 0.13 & 1.00 & & & & & & & \\
\hline GCAP & 0.09 & $0.55^{*}$ & 0.08 & $-0.55^{*}$ & 0.13 & -0.21 & -0.17 & $0.42 *$ & -0.05 & $-0.32 *$ & 1.00 & & & & & & \\
\hline CAT & -0.17 & -0.11 & 0.02 & 0.01 & 0.04 & 0.13 & -0.02 & $-0.34^{*}$ & 0.20 & -0.22 & 0.09 & 1.00 & & & & & \\
\hline ISLAM & $-0.25^{*}$ & -0.18 & -0.10 & -0.24 & 0.07 & $-0.28 *$ & 0.06 & 0.12 & 0.15 & 0.13 & 0.02 & $-0.41 *$ & 1.00 & & & & \\
\hline OTHR & $0.31 *$ & 0.24 & 0.16 & 0.11 & -0.09 & 0.20 & -0.04 & 0.23 & -0.23 & 0.09 & -0.03 & $-0.41 *$ & $-0.53^{*}$ & 1.00 & & & \\
\hline $\mathrm{EF}$ & 0.11 & $-0.42 *$ & 0.09 & 0.18 & 0.14 & 0.16 & $0.30^{*}$ & -0.14 & -0.06 & $0.53 *$ & $-0.35^{*}$ & -0.03 & -0.15 & 0.12 & 1.00 & & \\
\hline PODEN & 0.10 & 0.06 & -0.18 & 0.05 & -0.06 & 0.23 & -0.08 & 0.10 & 0.08 & -0.21 & -0.06 & 0.11 & -0.09 & 0.02 & $-0.35^{*}$ & 1.00 & \\
\hline PS & 0.11 & $0.43 *$ & 0.05 & -0.19 & $-0.33 *$ & 0.01 & -0.21 & $0.27 *$ & -0.12 & -0.23 & $0.39 *$ & -0.01 & $-0.28 *$ & $0.26^{*}$ & -0.22 & 0.10 & 1.00 \\
\hline
\end{tabular}

*Significant at $10 \%$. For the description of the variables and their main summary statistics see Table 1 and Table 2 , respectively. 


\section{Results}

This section presents regression results on the relationship between current institutional quality and both law and endowments while controlling for other possible determinants of institutional quality. White-adjusted heteroskedasticity robust standard errors (White, 1980) are used in all estimations. For each of the measures of current institutional quality used in this work, the empirical strategy consists in first estimating a baseline model with both the legal origins dummy (FLO) and the disease endowment proxy (MSI). The next step is to estimate a number of additive models by taking the baseline model and adding each of the control variables in turn. The controls which enter the additive models significantly are then included in the final models. The estimation results for the final models are reported in Table 4 and summarized in Table $5 .{ }^{15}$

Following the above approach, when the dependent variable is the strength of legal rights index (CRI), the estimation of the additive models reveals that only the coefficients of one of the religion variables (ISLAM) and of the proxy for political stability (PS) are statistically significant and display the expected signs. These variables are then included in the same model along with the legal origin dummy (FLO) and the measure of disease endowment (MSI) (MOD1 in Table 4). The estimations show that the French legal origin variable is significantly and negatively related to the strength of legal rights index, confirming the theoretical prediction that legal rights in lending tend to be better protected in African countries belonging to the British common law tradition. Results for MOD1 also reveal that ISLAM is statistically and negatively related to CRI, in line with the a priori expectations.

In the model with the depth of credit information index (CII) as dependent variable, when the additive regressions are run, GDP per capita, the ethnic fractionalization index and political

${ }^{15}$ The results of the estimations for the baseline models as well as for the additive models are not reported but are available from the authors upon request. 
stability are the controls that enter the estimations significantly. These are therefore the regressors that are included in the final model alongside the legal origin dummy (FLO) and the measure of disease endowment (MSI) (MOD2 in Table 4). The estimation results reveal that both FLO and MSI display the expected negative signs and are statistically significant. The GDP per capita and political stability controls also enter the model significantly and with the expected positive signs. The core findings from MOD2 lend support to the hypotheses put forward in this work, for they evidence that the credit information infrastructure is of lower quality in African countries of French civil law origin, as well as in countries with a higher malaria burden which in colonial times were less hospitable to the settlement of European colonizers.

Using time to enforce contracts (TEC) as dependent variable (MOD3 in Table 4), the findings show that, in line with theoretical expectations, enforcing contracts tends to take relatively longer in French civil law countries than in British common law ones, hence pointing towards the existence of more efficient judicial systems in the group of British legal origin countries. On the other hand, no cross-country differences in the time-efficiency of contract enforcement emerge in relation to the disease endowment that characterizes the sample countries. Moving to the vector of controls, the positive and statistically significant estimated coefficient on the "other religion" dummy seems to suggest that the judicial system tends to be relatively less efficient in countries in which the prevalent religious group is neither Protestant, nor Catholic or Muslim as enforcing contracts takes longer in these countries. Finally, countries which are more densely populated seem to do relatively better in terms of time required to enforce contracts.

Looking at the estimates obtained when the dependent variable is the cost to enforce contracts (CEC) (MOD4 in Table 4), legal origins and disease endowments do not seem to have 
a significant impact on this dimension of judicial system efficiency in the African context. Higher income levels, instead, have a positive effect on the efficiency of the judicial system, as the cost to enforce contracts is estimated to be lower in countries with higher GPD per capita. The observation that higher income countries tend to have more effective current institutions is well documented by earlier studies (e.g. Djankov et al., 2007; La Porta et al., 2008a). Results for MOD4 also evidence that in Africa the judicial system is relatively more efficient in countries where Islam is the prevalent religion as the cost to enforce contracts is lower in these countries.

The estimation results for procedures to register property (PRP) (MOD5 in Table 4) point to a country's legal origin and its disease endowment as determinants of the efficiency of its legal property system. Specifically, French common law countries as well as countries where the disease endowment is less favorable seem to require fewer procedures in order to register a property title. This seems to be the case also in countries where the political system is relatively more stable. On the other hand, more ethnically diverse countries appear to require a higher number of procedures to register property.

The second indicator used to proxy for the efficiency of a country's legal property system is time to register property (TRP). The results obtained from this cross-country regression (MOD6 in Table 4) suggest a positive and statistically significant relationship between the French civil law legal origin and the time required to register a property title. Specifically, across the sample African countries, registering a property title takes relatively longer in French civil law countries, than in British common law ones, indicating that the latter have a relatively more efficient legal property system. The statistically significant and positive coefficient on the 'other religion' dummy points towards longer property registration times in countries where the main religious group is neither Catholic, nor Muslim or Protestant. This appears to be case also in 
more densely populated countries, possibly due to a higher volume of logged registration applications.

The cost to register property (CRP) is the last indicator used to evaluate whether legal origins and disease endowment matter in determining the efficiency of a country's legal property system. None of the controls included in the additive models turns out to be statistically significant. On the other hand, the results for the baseline hence also final model (MOD7 in Table 4) lend support to both the legal origins and the disease endowment hypotheses, for they show that registering a property title costs less in countries of British common law legal origin as well as in countries that are less prone to malaria, hence were more hospitable to the creation of settlement colonies during colonial times.

The final regression in Table 4 refers to the model with the recovery rate for creditors (RRC) as dependent variable (MOD 8). Looking first at the key variables of interest, the French legal origin dummy is once again statistically significant and enters with the expected sign, suggesting that legal origins matter also in respect to the current degree of efficiency of a country's insolvency system. Specifically, this is greater in countries of British common law legal origin. The proxy for disease endowment (MSI), instead, does not seem to have a statistically significant relationship with RRC, even though from a qualitative viewpoint the direction of the link is as expected. Countries with higher levels of per capita income tend to develop more efficient insolvency systems. This is the case also in countries where the religion professed by the majority of the population is Islam, or a religion other than Protestantism, Catholicism or Islam. 
Table 4

Estimation results: Legal origins, disease endowments and institutional quality

\begin{tabular}{|c|c|c|c|c|c|c|c|c|}
\hline & $\begin{array}{c}\text { MOD1 } \\
C R I\end{array}$ & $\begin{array}{c}\text { MOD2 } \\
C I I\end{array}$ & $\begin{array}{c}\text { MOD3 } \\
T E C\end{array}$ & $\begin{array}{c}\text { MOD4 } \\
C E C\end{array}$ & $\begin{array}{c}\text { MOD5 } \\
P R P\end{array}$ & $\begin{array}{c}\text { MOD6 } \\
T R P\end{array}$ & $\begin{array}{c}\text { MOD7 } \\
C R P\end{array}$ & $\begin{array}{c}\text { MOD8 } \\
R R C\end{array}$ \\
\hline French legal origin & $\begin{array}{c}-3.173 * * * \\
(0.495)\end{array}$ & $\begin{array}{c}-0.682 * * \\
(0.368)\end{array}$ & $\begin{array}{c}173.705 * * \\
(83.543)\end{array}$ & $\begin{array}{c}-0.683 \\
(10.485)\end{array}$ & $\begin{array}{c}-1.146 * \\
(0.795)\end{array}$ & $\begin{array}{c}38.916 * * \\
(16.496)\end{array}$ & $\begin{array}{l}3.069 * * \\
(1.629)\end{array}$ & $\begin{array}{c}-7.903 * * \\
(4.775)\end{array}$ \\
\hline Malaria stability index & $\begin{array}{c}0.008 \\
(0.019)\end{array}$ & $\begin{array}{l}-0.036 * \\
(0.023)\end{array}$ & $\begin{array}{l}-4.947 \\
(4.308)\end{array}$ & $\begin{array}{c}0.418 \\
(0.504)\end{array}$ & $\begin{array}{c}-0.082 * * \\
(0.043)\end{array}$ & $\begin{array}{l}-0.455 \\
(1.111)\end{array}$ & $\begin{array}{c}0.294 * * * \\
(0.084)\end{array}$ & $\begin{array}{l}-0.168 \\
(0.245)\end{array}$ \\
\hline GDP per capita & & $\begin{array}{l}0.511 * * \\
(0.263)\end{array}$ & & $\begin{array}{c}-16.187 * * * \\
(4.704)\end{array}$ & & $\begin{array}{l}-7.774 \\
(9.008)\end{array}$ & & $\begin{array}{l}5.938 * * \\
(2.862)\end{array}$ \\
\hline Catholicism & $\begin{array}{l}-0.287 \\
(0.291)\end{array}$ & & $\begin{array}{c}91.116 \\
(85.259)\end{array}$ & $\begin{array}{l}-18.590 \\
(17.485)\end{array}$ & $\begin{array}{c}0.923 \\
(0.943)\end{array}$ & $\begin{array}{c}16.239 \\
(23.925)\end{array}$ & & $\begin{array}{l}-4.321 \\
(6.062)\end{array}$ \\
\hline Islam & $\begin{array}{l}-0.618 * \\
(0.397)\end{array}$ & & $\begin{array}{c}58.105 \\
(70.543)\end{array}$ & $\begin{array}{c}-33.734 * * \\
(15.591)\end{array}$ & $\begin{array}{c}1.084 \\
(0.991)\end{array}$ & $\begin{array}{l}-10.386 \\
(14.626)\end{array}$ & & $\begin{array}{l}9.383 * * \\
(4.395)\end{array}$ \\
\hline Other religion & $\begin{array}{l}0.0918 \\
(0.388)\end{array}$ & & $\begin{array}{c}207.122 * * * \\
(76.299)\end{array}$ & $\begin{array}{l}-19.474 \\
(16.284)\end{array}$ & $\begin{array}{c}0.686 \\
(0.848)\end{array}$ & $\begin{array}{l}31.488 * * \\
(17.807)\end{array}$ & & $\begin{array}{l}9.191 * * \\
(4.002)\end{array}$ \\
\hline Ethnic fractionalization index & & $\begin{array}{l}-1.018 \\
(0.930)\end{array}$ & & & $\begin{array}{l}1.972 * \\
(1.375)\end{array}$ & $\begin{array}{c}50.421 \\
(39.637)\end{array}$ & & \\
\hline Population density & & & $\begin{array}{c}-0.578 * * \\
(0.267)\end{array}$ & & & $\begin{array}{l}0.117 * \\
(0.071)\end{array}$ & & \\
\hline Political stability & $\begin{array}{l}-0.064 \\
(0.280) \\
\end{array}$ & $\begin{array}{c}0.339 * * \\
(0.194)\end{array}$ & & & $\begin{array}{c}-0.911 * * \\
(0.402)\end{array}$ & & & $\begin{array}{c}1.642 \\
(2.428) \\
\end{array}$ \\
\hline Number of countries & 46 & 46 & 46 & 46 & 46 & 46 & 46 & 46 \\
\hline R-squared & 0.701 & 0.493 & 0.176 & 0.384 & 0.284 & 0.279 & 0.345 & 0.404 \\
\hline F-statistic & 46.240 & 5.91 & 2.28 & 5.24 & 2.510 & 1.780 & 17.06 & 7.280 \\
\hline P-value of F-statistic & 0.000 & 0.000 & 0.056 & 0.000 & 0.032 & 0.013 & 0.000 & 0.000 \\
\hline
\end{tabular}

For the description of the variables see Table 1. Robust standard errors are given in parentheses. All regressions include the constant term. The omitted legal origin is the British legal origin. The omitted religion is Protestantism. *, **, *** indicate significance at the $10 \%, 5 \%$ and $1 \%$ levels, respectively. 
Table 5

Legal origins, disease endowments and current institutional quality based on the legal origin categorization of La Porta et al. (1999) and La Porta et al. (2008b)

\begin{tabular}{l|lr}
\hline & LEGAL ORIGIN & DISEASE ENDOWMENT \\
\hline Strength of legal rights index & $\begin{array}{l}\text { Significant and in hypothesized } \\
\text { direction }\end{array}$ & Not significant \\
\hline Depth of credit information index & $\begin{array}{l}\text { Significant and in hypothesized } \\
\text { direction }\end{array}$ & $\begin{array}{r}\text { Significant and in hypothesized } \\
\text { direction }\end{array}$ \\
\hline Time to enforce contracts & $\begin{array}{l}\text { Significant and in hypothesized } \\
\text { direction }\end{array}$ & Not significant \\
\hline Cost to enforce contracts & Not significant & Not significant \\
\hline Procedures to register property & $\begin{array}{l}\text { Significant and in hypothesized } \\
\text { direction }\end{array}$ & Significant and in hypothesized \\
direction
\end{tabular}

\subsection{Robustness Checks}

The results so far presented are based on the classification of legal origins provided by La Porta et al. (1999) and La Porta et al. (2008b). Klerman et al. (2011) propose an alternative classification of legal origins based on the claim that some of the countries in the British legal origin group are actually better classified as mixed legal origin. To check the robustness of the results, following the coding in Klerman et al. (2011), the legal origin of Swaziland is recoded into French (instead of British) and the legal origin of Mauritius into mixed (instead of French). In addition, the following six countries are re-categorized as mixed legal origin instead of British: Botswana, Lesotho, Mauritius, Namibia, South Africa and Zimbabwe. All regressions are then re-run using this new classification of the sample countries. The findings presented in 
the previous section are all confirmed with the exception of one. Specifically, legal origins do not turn out to be statistically significantly related to the depth of credit information index, even though the qualitative result remains unchanged. The estimation results from these robustness check are not reported due to space constraints. They are however summarized in Table 6.

Table 6

Legal origins, disease endowments and current institutional quality based on the legal origin categorization of Klerman et al. (2011)

\begin{tabular}{l|lr}
\hline & LEGAL ORIGIN & DISEASE ENDOWMENT \\
\hline Strength of legal rights index & $\begin{array}{l}\text { Significant and in hypothesized } \\
\text { direction }\end{array}$ & Not significant \\
\hline Depth of credit information index & $\begin{array}{l}\text { Significant and in hypothesized } \\
\text { direction }\end{array}$ & $\begin{array}{r}\text { Significant and in hypothesized } \\
\text { direction }\end{array}$ \\
\hline Time to enforce contracts & $\begin{array}{l}\text { Significant and in hypothesized } \\
\text { direction }\end{array}$ & Not significant \\
\hline Cost to enforce contracts & Not significant & Not significant \\
\hline Procedures to register property & $\begin{array}{l}\text { Significant and in hypothesized } \\
\text { direction }\end{array}$ & Significant and in hypothesized \\
direction
\end{tabular}

For the description of the variables see Table 1. Statistically significant variables are indicated in bold.

\section{Discussion and conclusion}

This research work offered an empirical study of the relationship between cross-country differences in institutions inherited from the past and variation in current institutional quality in Africa. The main concern has been to examine whether and to what extent historical factors which are rooted in a country's legal origin and disease endowment, affect significantly the 
quality of current institutions that are seen as determinants of financial system development, as well as of other economic outcomes, in the prevalent literature.

The empirical evidence gathered in the study lends strong support to the legal origins hypothesis. The cross-country regressions show that African countries of British legal origin tend to offer better protection of legal rights in lending, have a more developed credit information infrastructure, as well as more efficient judicial, legal property and insolvency systems. These findings are in line with studies such as Djankov et al. (2007), Djankov et al. (2008) and La Porta et al. (2013), among others.

As far as the endowment hypothesis is concerned, this finds some support in the estimations. The results evidence that the credit information infrastructure is less developed and the legal property system is less efficient in African countries where the disease endowment is more conducive to malaria, hence in former colonies where Europeans set-up extractive institutions. Although these findings lend some support to the claims put forward by the disease endowment theory (Acemoglu et al., 2001) and the empirical evidence on its validity in other contexts (Beck et al., 2003; Oto-Peralias and Romero-Avila, 2014), generally the quality of the current institutions examined in this work does not seem to be linked to the colonization strategies that were adopted as a result of the disease endowment in colonized territories.

The findings have policy implications. The fact that the legal origins hypothesis received strong empirical support suggests that historical institutional factors matter for the quality of contemporary institutions within the African context. Policy makers should be conscious that poor quality contemporary institutions in African countries, and elsewhere, may be the result of detrimental institutional structures inherited from colonial times. Issues of lock-in, path dependence and institutional complementarities may make those structures resistant to change, 
hence hindering the effectiveness of reforms aimed at improving the quality of current institutions. Arguably, this has not been sufficiently, if at all, stressed by most previous studies in this line of research, not even by those which have had significant influence over the policy reforms designed by international development organizations and individual governments alike.

This paper is not without limitations. The empirical work is focused on African former European colonies and hence the findings may not be generalizable beyond the African context. Future research should therefore verify the results from this study for other continents. For example, studies can be carried out for Latin America and the Caribbean, as well as for Central, East and South-East Asia. Moreover, the use of case studies and historical narratives in future research would be a welcome step towards attempting to offer a more comprehensive causal interpretation of the links among historical and current institutions.

In conclusion, overall considered, the empirical evidence gathered in this paper corroborates the core argument of the study: historical factors, legal origins in particular, have long-lasting effects on current institutional quality across Africa. 
Appendix 1: Sample countries with legal origins categorization of La Porta et al. (1999) and La Porta, Lopez-de-Silanes and Shleifer (2008a)

\begin{tabular}{|l|c|l|c|}
\hline Country & Legal origin & Country & Legal origin \\
\hline Algeria & FLO & Lesotho & ELO \\
Angola & FLO & Madagascar & FLO \\
Benin & FLO & Malawi & ELO \\
Botswana & ELO & Mali & FLO \\
Burkina Faso & FLO & Mauritania & FLO \\
Burundi & FLO & Mauritius & FLO \\
Cameroon & FLO & Morocco & FLO \\
Cape Verde & FLO & Mozambique & FLO \\
Central African Republic & FLO & Namibia & ELO \\
Chad & FLO & Niger & FLO \\
Comoros & FLO & Nigeria & ELO \\
Congo, Democratic Republic & FLO & Rwanda & FLO \\
Congo, Republic & FLO & Senegal & FLO \\
Cote d'Ivoire & FLO & Sierra Leone & ELO \\
Djibouti & FLO & South Africa & ELO \\
Egypt, Arab Republic & FLO & Sudan & ELO \\
Equatorial Guinea & FLO & Swaziland & ELO \\
Gabon & FLO & Tanzania & ELO \\
Gambia & ELO & Togo & FLO \\
Ghana & ELO & Tunisia & FLO \\
Guinea & FLO & Uganda & ELO \\
Guinea-Bissau & FLO & Zambia & ELO \\
Kenya & ELO & Zimbabwe & ELO \\
\hline
\end{tabular}

Note: $\mathrm{FLO}=$ French legal origin; ELO = British legal origin 


\section{Acknowledgements}

The authors are very grateful to two anonymous referees for their valuable comments and suggestions on an earlier version of this paper. All remaining shortcomings are their own. 


\section{References}

Acemoglu, D., Johnson, S., Robinson, J.A., 2001. The Colonial Origins of Comparative Development: An Empirical Investigation. The American Economic Review 91, 13691401.

Ahmed, A.D., 2010. Financial liberalization, financial development and growth linkages in SubSaharan African countries. Studies in Economics and Finance 27, 314-339.

Alesina, A., Baqir, R., Easterly, W., 1999. Public goods and ethnic divisions. The Quarterly Journal of Economics 114, 1243-1284.

Alesina, A., Devleeschauwer, A., Easterly, W., Kurlat, S., Wacziarg, R., 2003. Fractionalization. Journal of Economic Growth 8, 155-194.

Arcand, J.L., Berkes, E., Panizza, U., 2015. Too much finance? Journal of Economic Growth 20, $105-148$.

Arrunada, B., 2010. Protestants and Catholics: Similar work ethic, different social ethic. The Economic Journal 120, 890-918.

Arthur, W. B., 1989. Competing technologies, increasing returns, and lock-in by historical events. Economic Journal 99, 116-131.

Ayyagari, M., Demirguc-Kunt, A., Maksimovic, V., 2008. How Well Do Institutional Theories Explain Firms' Perceptions of Property Rights? Review of Financial Studies 21, 1833 1871.

Beck, T., 2013. Finance, growth, and fragility: The role of government. International Journal of Banking, Accounting and Finance 5, 49-77.

Beck, T., Demirguc-Kunt, A., 2006. Small and medium-size enterprises: Access to finance as a growth constraint. Journal of Banking \& Finance 30, 2931-2943. 
Beck, T., Demirguc-Kunt, A., Laeven, L., Maksimovic, V., 2006. The determinants of financing obstacles. Journal of International Money and Finance 25, 932-952.

Beck, T., Demirguc-Kunt, A., Levine, R., 2001. Legal theories of financial development. Oxford Review of Economic Policy 17, 483-501.

Beck, T., Demirguc-Kunt, A., Levine, R., 2003. Law, endowments, and finance. Journal of Financial Economics 70, 137-181.

Beck, T., Demirguc-Kunt, A., Maksimovic, V., 2005. Financial and Legal Constraints to Growth: Does Firm Size Matter? The Journal of Finance 60, 137-177.

Beck, T., Levine, R., 2005. Legal institutions and financial development, in: Menard, C., Shirley, M. (Eds.), Handbook of New Institutional Economics. Springer, The Netherlands, pp. 251278.

Beck, T., Maimbo, S.M., Faye, I., Triki, T., 2011. Financing Africa: Through the crisis and beyond. The International Bank for Reconstruction and Development/The World Bank, Washington DC,USA.

Besley, T., 2015. Law, regulation, and the business climate: The nature and influence of the World Bank Doing Business Project. The Journal of Economic Perspectives 29, 99-120.

Boukhatem, J., 2016. Assessing the direct effect of financial development on poverty reduction in a panel of low- and middle-income countries. Research in International Business and Finance 37, 214-230.

Brown, M., Jappelli, T., Pagano, M., 2009. Information sharing and credit: Firm-level evidence from transition countries. Journal of Financial Intermediation 18, 151-172.

Carr, J.L., Landa, J.T., 1983. The economics of symbols, clan names, and religion. The Journal of Legal Studies 12, 135-156. 
Carstensen, K., Gundlach, E., 2006. The primacy of institutions reconsidered: Direct income effects of malaria prevalence. The World Bank Economic Review 20, 309-339.

David, P. (1985) 'Clio and the Economics of QWERTY', The American Economic Review, 75, pp. 332-337.

David, P. (2007) 'Path dependence, its critics and the quest for historical economics', in Hodgson, G. M. (ed) The Evolution of Economic Institutions. A Critical Reader, Cheltenham: Edward Elgar.

De Soto, H., 2001. The mystery of capital. Finance and Development 38, 1.

de Sousa, J., Lochard, J., 2012. Trade and colonial status. Journal of African Economies 21, 409439.

Deakin, S., Demetriades, P., James, G.A., 2010. Creditor protection and banking system development in India. Economics Letters 108, 19-21.

Demirguc-Kunt, A., Love, I., Maksimovic, V., 2006. Business environment and the incorporation decision. Journal of Banking \& Finance 30, 2967-2993.

Djankov, S., Georgieva, D., Ramalho, R., 2018. Business regulations and poverty. Economics Letters $165,82-87$.

Djankov, S., Hart, O., McLiesh, C., Shleifer, A., 2008. Debt Enforcement around the World. Journal of Political Economy 116, 1105-1149.

Djankov, S., McLiesh, C., Shleifer, A., 2007. Private credit in 129 countries. Journal of Financial Economics 84, 299-329.

Easterly, W., and R. Levine (1997) 'Africa's growth tragedy: policies and ethnic divisions', The Quarterly Journal of Economics, 112(4): 1203-1250.

Easterly, W., and R. Levine (2003) 'Tropics, germs and crops: how endowments influence 
economic development', Journal of Monetary Economics 50, 3-39.

Easterly, W., Ritzen, J., Woolcock, M., 2006. Social cohesion, institutions, and growth.

Economics \& Politics 18, 103-120.

Emenalo, C.O., Gagliardi, F., Hodgson, G.M., 2018. Historical institutional determinants of financial system development in Africa. Journal of Institutional Economics 14, 345-372.

Fowowe, B., 2017. Access to finance and firm performance: Evidence from African countries. Review of Development Finance 7, 6-17.

Gagliardi, F. 2008. Institutions and economic change: A critical survey of the new institutional approaches and empirical evidence. The Journal of Socio-Economics 37(1), 416-443.

Gagliardi, F. 2019. A bibliometric analysis of the journal literature on institutional complementarities. mimeo.

Gallup, J.L., Sachs, J.D., Mellinger, A.D. 1998. Geography and economic development. Working paper no. 6849, National Bureau of Economic Research.

Gennaioli, N., La Porta, R., Lopez-de-Silanes, F., Shleifer, A., 2014. Growth in regions. Journal of Economic Growth 19, 259-309.

Haselmann, R., Pistor, K., Vig, V., 2010. How Law Affects Lending. Review of Financial Studies 23, 549-580.

Hearn, B., 2014. Institutional impact on the expropriation of private benefits of control in North Africa. Research in International Business and Finance 30, 1-23.

Hearn, B., Filatotchev, I., 2019. Founder retention as CEO at IPO in emerging economies: The role of private equity owners and national institutions. Journal of Business Venturing 34, 3, 418-438.

Hearn, B., Jackson, G., Nakajima, C. 2013. Corporate governance and national institutions: A 
review and emerging research agenda. Asia Pacific Journal of Management 30, 965-986.

Hearn, B., Oxelheim, L., Randoy, T., 2018. The institutional determinants of private equity involvement in business groups-The case of Africa. Journal of World Business 53, 118133.

Honohan, P., Beck, T., 2007. Making finance work for Africa. The World Bank, Washington, DC, USA.

Ibrahim, M., Alagidede, P., 2018. Nonlinearities in financial development-economic growth nexus: Evidence from sub-Saharan Africa. Research in International Business and Finance 46, 95-104.

Kaldor, N., 1967. Strategic Factors in Economic Development. Ithaca, New York: Cornell University Press.

Kapp, K. W., 1976. The nature and significance of institutional economics. Kyklos 29, 209-232.

Kaufmann, D., Kraay, A., Mastruzzi, M., 2010. The Worldwide Governance indicators:

Methodology and analytical issues. World Bank Policy Research Working Paper No. 5430.

Kiszewski, A., Mellinger, A., Spielman, A., Malaney, P., Sachs, S.E., Sachs, J.D., 2004. A global index representing the stability of malaria transmission. The American Journal of Tropical Medicine and Hygiene 70, 486-498.

Klerman, D.M., Mahoney, P.G., Spamann, H., Weinstein, M.I., 2011. Legal Origin or Colonial History? Journal of Legal Analysis 3, 379-409.

La Porta, R., Lopez-de-Silanes, F., Shleifer, A., 2013. Law and Finance After a Decade of Research, in: Constantinides, G.M., Harris, M., Stulz, R.M. (Eds.), Handbook of the Economics of Finance. Elsevier BV, Amsterdam, The Netherlands, pp. 425-491.

La Porta, R., Lopez-de-Silanes, F., Shleifer, A., 2008a. The economic consequences of legal 
origins. Journal of Economic Literature 46, 285-332.

La Porta, R., Lopez-de-Silanes, F., Shleifer, A., 2008b. Dataset for the paper: The economic consequences of legal origins. http://www.economics.harvard.edu/faculty/shleifer/dataset.

La Porta, R., Lopez-de-Silanes, F., Shleifer, A., Vishny, R.W., 1999. The quality of government. Journal of Law, Economics, and organization 15, 222-279.

La Porta, R., Lopez-de-Silanes, F., Shleifer, A., Vishny, R.W., 1998. Law and finance. The Journal of Political Economy 106, 1113-1155.

La Porta, R., Lopez-de-Silanes, F., Shleifer, A., Vishny, R.W., 1997. Legal Determinants of External Finance. The Journal of Finance 52, 1131-1150.

Levine, R., 2005. Finance and Growth: Theory and Evidence, in: Aghion, P., Durlauf, S.N. (Eds.), Handbook of Economic Growth. Elsevier B. V., The Netherlands, pp. 865-934.

McCleary, R.M., Barro, R.J., 2006. Religion and economy. The Journal of Economic Perspectives 20, 49-72.

McCord, G.C., 2012. A global index representing the stability of malaria transmission countrylevel dataset. https://sites.google.com/site/gordoncmccord/datasets.

McDonald, C., Schumacher, L., 2007. Financial deepening in Sub-Saharan Africa: Empirical evidence on the role of creditor rights protection and information sharing. Working paper series WP/07/203. The International Monetary Fund (IMF), Washington, DC.

Murinde, V., 2012. Financial Development and Economic Growth: Global and African Evidence. Journal of African Economies 21, i10-i56.

Myrdal, G. (1957) Economic Theory and Underdeveloped Regions, London: Duckworth.

North, D. C. (1990) Institutions, Institutional Change and Economic Performance, Cambridge: Cambridge University Press. 
Otchere, I., Senbet, L., Simbanegavi, W., 2017. Financial sector development in Africa-an overview. Review of Development Finance 7, 1-5.

Oto-Peralias, D., Romero-Avila, D., 2014. Legal traditions and initial endowments in shaping the path of financial development. Journal of Money, Credit and Banking 46, 43-77.

Pistor, K., Raiser, M., Gelfer, S., 2000. Law and finance in Transition Economies. Economics of Transition 8, 325-368.

Sachs, J.D., Chambers, R.G., 2009. The new global war on malaria, in: Clapham, A., Robinson, M. (Eds.), Realizing the Right to Health. Ruffer \& Rub, Zurich, pp. 305-323.

Schnyder, G., Siems, M., Aguilera, R., 2018. Twenty years of 'Law and Finance': time to take law seriously, Socio-Economoc Review 00, 1-30.

Siems, M., Deakin, S., 2010. Comparative law and finance: Past, present, and future research. Journal of Institutional and Theoretical Economics 166, 120-140.

Skosples, G., 2012. Law and credit constraints in transition economies. Economics of Transition $20,425-455$.

Stulz, R.M., Williamson, R., 2003. Culture, openness, and finance. Journal of Financial Economics 70, 313-349.

Weber, M., 1930. The protestant ethic and the spirit of capitalism. London: George Allen \& Unwin Ltd.

White, H., 1980. A heteroskedasticity-consistent covariance matrix estimator and a direct test for heteroskedasticity. Econometrica 48, 817-838.

World Bank, 2017a. Doing Business Project: Historical data sets and trends data. http://www.doingbusiness.org/Custom-Query.

World Bank, 2017b. World development indicators. http://data.worldbank.org/data- 
catalog/world-development-indicators.

World Bank, 2017c. Doing Business Project: Methodology notes.

http://www.doingbusiness.org/methodology/methodology-note.

World Bank, 2016. The Worldwide Governance Indicators (WGI) Project dataset. http://info.worldbank.org/governance/wgi/\#home.

World Bank, 2013. Doing Business 2014: Understanding Regulations for Small and MediumSize Enterprises. World Bank Group, Washington, DC.

World Bank, 2012. Doing Business 2012: Doing business in a more transparent world. World Bank Group, Washington, DC.

Young, A. A., 1928. Increasing Returns and Economic Progress. Economic Journal 28(4), 527542 